\title{
Alterations of materials at the façades of the church of San Pedro de Mezonzo (A Coruña, NW Spain)
}

\author{
Carlos Alves, ${ }^{1}$ Jorge Sanjurjo-Sánchez ${ }^{2}$
}

${ }^{1}$ Centro de Investigação Geológica, Ordenamento e Valorização de Recursos

(Suported by Fundação para a Ciência e a Tecnologia with Portuguese Funds

- PEst-OE/CTE/UI0697/2011), Departamento de Ciências da Terra, Escola de Ciências, Universidade do Minho, Braga, Portugal

e-mail: casaix@dct.uminho.pt,

${ }^{2}$ University Institute of Geology, University of A Coruña, Edificio Servizos

Centrais de Investigación, Campus de Elviña, A Coruña, Spain

e-mail: jsanjurjo@udc.es

The Church of San Pedro de Mezonzo is located in the A Coruña city center and its main façade is exposed to the east. It is mostly made of granite stones but there are other stony and metallic materials applied. The outside of the church is comprised mostly of ashlars and plastered walls but there are also some examples of carved stone (statuary) on the main façade that are mostly made of granite.

An observational study based on visual detection of alteration features showed the presence of:

- diverse stains;

- erosive features with loss of material.

The dark brownish/reddish stains are related to the presence of ferrous elements on the main façade. The whitish efflorescences detected on the granite ashlars of the main façade are mostly composed of alkaline sulphates. There are also some widespread darkish coatings on the granite ashlars that might reach the thickness of a black crust. This also occurs on other materials and on the carved statuary.

The erosive features affect the plastered walls and seem to mark water infiltration points as well as the granite ashlars. The proximity of the efflorescences to the erosive features suggests a causal association between the erosive features and salt weathering.

These decay features indicate that the decay of the materials results from exogenous agents (e.g. water, atmospheric materials) and also from the materials that are used in the construction of the church. Of particular relevance are the ugly brown/reddish stains associated with the metallic elements and the intense erosive features observed on the granite ashlars that seem related to the alkaline sulphates (usually related with cement mortars), features that indicate the contribution of the materials used on the built structure. 